\title{
Teori Eksplanatoris Pola Penggunaan Lahan
}

Nurfatimah, Universitas Islam Negeri Alauddin Makassar nurfatimah.nurfatimah91@gmail.com

Teori eksplanatoris menjelaskan bagaimana proses terbentuknya pola penggunaan lahan sehingga membentuk struktur spasial suatu wilayah. Dalam menjelaskan bagaimana proses terbentuknya pola penggunaan lahan ini, teori lokasi merupakan teori dasar dalam analisa spasial.

\section{A. Teori Von Thunen}

Von thunen merupakan pelopor teori lokasi yang berasal dari Jerman, Berkaitan dengan pola penggunaan lahan, Von Thunen menggunakan 7 (tujuh) asumsi, yaitu sebagai berikut:

1. Wilayah terasing (isolated stated), yang terdiri atas sebuah kota dan wilayah pertanian sebagai wilayah belakangnya (hinterland).

2. Kota tersebut merupakan pasar bagi surplus hasil pertanian dari hinterland dan tidak menerima hasil pertanian dari wilayah lain.

3. Hinterland tersebut hanya menjual hasil pertaniannya ke kota itu saja dan tidak ke kota lain.

4. Hinterland mempunyai lingkungan alam yang homogeny dan keadaan yang baik bagi tanaman dan peternakan.

5. Hinterland dihuni oleh petani - petani yang menginginkan keuntungan maksimum dan mapu penyesuaian tipe pertaniannya dengan permintaan pasar.

6. Hinterland hanya mempunyai 1 macam angkutan darat tertentu (pada zaman itu) yaitu gerobak ditarik kuda.

7. Biaya angkutan berbanding langsung dengan jarak perjalanan dan seluruh pengangkutan hanya digunakan oleh para petani yang mengirimkan hasil pertaniannya.

Von Thunen mengemukakan bahwa beberapa tanaman niaga cenderung untuk berlokasi menurut pola tertentu. Di sekeliling kota akan terbentuk berbagai tipe pertanian yang merupakan beberapa lingkaran sepusat. Pola penggunaan lahan sangat ditentukan oleh biaya transportasi yang dikaitkan dengan jarak dan sifat barang dagangan khususnya hasil pertanian. 
Teori Von Thunen ini memiliki kekurangan, antara lain bahwa semua kota tidak memiliki kondisi fisik lingkunan yang sama. Kota akan memiliki pola penggunaan lahan yang berbeda - beda sesuai dengann karakteristik wilayahnya.

\section{B. Teori Klasik Penggunaan Lahan Alonso}

Seperti yang telah dijelaskan di atas bahwa teori penggunaan lahan Von Thunen memiliki kekurangan, antara lain semua kota tidak memiliki kondisi fisik lingkungan yang sama. Bedasarkan kekurangan tersebut, William Alonso (1954) kemudian mengembangkan teori lain, yaitu 'Teori Bid Rent' (Teori Sewa Tanah). Teori klasik guna lahan Alonso ini bersumber pada teori ekonomi, yaitu adanya interaksi nilai lahan dan penggunaan lahan (antara penyediaan dan permintaan). Sedikit pebedaanya dengan Von thunen, model Alonso tidak saja menekankan masalah perdesaan, namun juga berkaitan dengan wilayah perkotaan.

Di dalam penetapan penggunaan lahan berdasarkan mekanisme pasar model Alonso menjelaskan kaitan antara sisi permintaan (yang merupakan turunan dari system aktivitas) dan factor lahan dan lokasidari sisi penyediaan (yang merupakan turunan dari sistemn pengembangan lahan). Namun, kelemahan dari teori Alonso ini adalah transport dianggap ada dimana - mana dan biaya transport berbanding lurus dengan jarak dari semua lokasi.

\section{Teori Penggunaan Lahan yang Berorientasi Transportasi}

Teori guna lahan yang berorientasi transportasi (Wingo, 1961) berbasis teori ekonomi yaitu keseimbangan antara aksesilitas dengan nilai lahan Aksesibilitas di ukur dengan waktudan biaya yang besarnya bergantung pada jarak dn banaknya perjalanan yang dilakukan (Chapin, 1979).dari sisi suplai suatu lahan dengan jangkauan transportasi yang baik mempunyai nilai ekonomi relative lebih baik, karena akan mengurangi biaya perjalann dan waktu tempuh. Dengan demikian, dalam konteks keseimbangan rumah tangga, kemampuan membeli tanah dipengaruhi juga oleh keaksesibelan suatu lokasi dalam struktur spasial perkotaan.

D. Nilai Sosial Dalam Teori Penggunaan Lahan

Dalam konteks model keseimbangan umum dalam hubungannya dengan lokasi tempat tinggal dan struktur spasial perkotaan menurut Walter Firey (1947), pemilihan lokasi dipengaruhi juga oelh nilai social, rasa, dan symbol yang memiliki nilai sangat 
bervariasi bergantung pada strata social dan etnik grup dalam msyarakat plural. Teori ini dapat menjelaskan bahwa pemilihan lokasi suatu kelompokm masyarakat, tidak hanya ditentukan oleh 'market consideration' tapi juga merupakan respons dari nilai social. Rasa kedekatan, nyaman, dan kemudahan beradaptasi dengan lingkungan merupakansalah satu factor dari respons nilai social. Dengan demikian, dapat dijelaskan bahwa suatu lokasi yang relative jauh dari pusat kotad dapat memiliki nilai tanah yang relative tinggi sebagai respons dari suatu symbol misalnya: lokasi tersebut memiliki symbol sebagai lokasi permukiman golongan mewah, dan adanya pengelompokan permukiman kelompok etnik tertentu dalam struktur spasial perkotaan.

\section{E. Teori Penggunaan Lahan Weber}

Jika teori - teori sebelumnya menjelaskan pemilihan lokasi berdasarkan kemampuan membayar harga tanah, maka Albert Weber (1929) mempelopori pembentukan teori lokas khusus untuk kegiatan industry pengolahan (manufacturing), yaitu mencari lokasi industry yang terbaik (optimal) di antara lokasi bahan baku dan pasar, yang dapat memberikan ongkos angkut minimal, yang besarannya ditentukan oleh perbandingan antara ongkos angkut bahan baku dan hasil produksi per unit (Syahrizal, 2008).

\section{F. Teori Penggunaan Lahan Berorientasi Market}

Teori penggunaan lahan berorientasi market dipelopori oleh August Losch (1944) yang mendasarkan analisis pemilihan lokasi optimal berdasarkan luas pasar yang dapat dikuasai dan kompetisi antar tempat. Berdasarkan pandangan ini, sebuah perusahaan akan memilih suatu tempat sebagai lokasi yang optimal berdasarkan kekuatan persaingan antar tempat dan luas pasar yang dikuasainya. Dengan demikian, permintaan dan penawaran antar tempat merupakan unsur penting dalam menentukan lokasi optimal dan suatu kegiatan perusahaan (Syahrizal,2008).

Dari beberapa teori eksplanatoris terbentuknya pola penggunaan lahan di atas, dengan asumsi kondisi fisik lingkungan sama, dapat diindikasikan bahwa

1. Aspek ekonomi (antara lain kemampuan membeli tanah dan perhitungan perolehan keuntungan maksismun)

2. Aspek aksesibilitas 
3. Aspek nilai social, rasa dan symbol merupakan factor penentu penggunaan lahan.

\section{DAFTAR PUSTAKA}

Bintarto, R. (1977). Pengantar geografi kota. Spring.

Jayadinata, J. T. (1986). Tata guna tanah dalam perencanaan pedesaan, perkotaan dan wilayah. Penerbit Itb.

Kaiser, E. J., Godschalk, D. R., \& Chapin, F. S. (1995). Urban land use planning (Vol. 4). Urbana: University of Illinois press.

Koestoer, R. H. (1996). Penduduk dan aksesibilitas kota: perspektif tata-ruang lingkungan Ujung Pandang. Penerbit Universitas Indonesia.

Sitawati, Anita. (2016). Materi Pokok Tata Guna dan Pengembangan Lahan. Tangerang Selatan : Universitas Terbuka.

Sjafrizal, \& Elfindri. (2008). Ekonomi regional: teori dan aplikasi. Baduose Media.

Yusran, A. (2006). Kajian Perubahan Tata Guna Lahan pada Pusat Kota Cilegon (Doctoral dissertation, Program Pascasarjana Universitas Diponegoro). 